\title{
EVALUATION OF SOME NEWLY INTRODUCED SUGAR BEET CULTIVARS UNDER EGYPTIAN NORTH-DELTA CONDITIONS:
}

I- YIELD AND YIELD COMPONENTS

El-Kammash, T. N. ${ }^{1}$; M. M. Abdelkader ${ }^{1}$; M. A. Farag ${ }^{2}$; E. A. Teama $^{3}$ and A. M. Abou-Salama ${ }^{3}$

1 Dakahlia Sugar Company

${ }^{2}$ Sugar Crops Research Institute, ARC, Giza

${ }^{3}$ Agronomy Dept., Faculty of Agriculture, Assiut University, Egypt

\begin{abstract}
This work was carried out during 2008-2009 and 2009-2010 seasons to evaluate fourteen imported sugar beet cultivars under the farm conditions of Abo Taha village, Belkas district, Dakahlia Governorate region (latitude $31^{\circ} 15^{\prime} \mathrm{N}$ ) to determine their merit as possible candidates to be distributed to farmers. Seven of the evaluated cultivars, namely Henrike, BTS 899, Beretta, Lagon, Lp15, Lp16, and Avantage belonged to monogerm type while another group of seven cultivars, namely; Monte Bianco, Monte Baldo, Monte Rosa, Swallow, Top, Capel, and Floima belonged to multi-germ type.

The main findings of this work could be summarized as follows:

1- Root yield per feddan of mono-germ cultivars exceeded that of multigerm cultivars significantly, with an average value of 0.576 and 0.772 tons per feddan for the first and second seasons, respectively. However the differences recorded for most of the remained traits were insignificant.

2- The results indicated that, the monogerm cultivars Lp 16 and BTS 899 were the most promising ones under the experimental conditions with an average value of 39.081 and 37.998 tons/ feddan as the mean of both seasons, respectively. Moreover the multigerm cultivars Monte Bianco and Capel produced maximum root yield of this group with values of 38.675 and 37.940 tons/feddan as the mean of both seasons, respectively. In the two seasons. These values of Monte Bianco were statistically similar to the monogerm group .

3- The results indicated that, seed type of sugar beet cultivars had no significant effect on sugar recovery per feddan. While cultivars within each type significantly differed in both seasons. Moreover the three monogerm cultivars Lagon, Lp15, Lp16 and two multigerm cultivars Monte Bianco, Capel gave maximum yield from sugar recovery per feddan under the experimental conditions.

4- It could be recommended based on these finding that monogerm cultivars Lagon, Lp15, Lp16 and multigerm Monte Bianco as well as Capel cultivars can be distribute to farmers in the experimental site region for maximum sugar recovery per feddan.
\end{abstract}

\section{INTRODUCTION}

Sugar beet is the second major source for sugar production in Egypt. The Egyptian strategy adopts expanding beet farming and manufacturing as the main method to narrow the gap between sugar production and consumption. However, the whole farming system depends on importing 
seed from abroad as the conditions prevailed in Egypt do not allow for seed production under the Egyptian condition. Thus it is essential to test and evaluate the cultivars that are imported before deciding on distributing it to farmers. One main factor is to determine whether the imported cultivars will perform well under the relatively warm weather of Egyptian terms of yield and quality. Works on evaluating beet cultivars are numerous all over the world.

Jassem (1982) reported that mono-germ sugar beet varieties had lower sugar beet content. He found that mono-germ varieties are higher yielding than multi-germ varieties.

Szklarz and woijcik (1983) evaluated some sugar beet varieties and showed that root yield was highest in Trimono (40.9 t/ha.) however leaf yield was greatest in PN Mono 2 variety (61.6 t/ha.). They added that sugar content of the roots ranged from $14.05 \%$ in PN mono 2 to $17.85 \%$ in Trimono. Similar differences were also reported by Tripathi et al. (1986) for root yield per hectare. Variation ranged from 39 to 70 tons in yield of root /ha.

Said (1993) noticed that Kawemira cultivar recorded the highest value of root fresh, root diameter and root length. Similar findings were reported for yield of root as compared with other cultivars.

Ahmed et al. (1998) concluded that Sibel cv. From Belgium and KWS Pak-492 from German origin gave almost similar and the highest average root yields (79.78 and 79.22 t/ha., respectively). Sibel, KWS Pak-492 and M9255 were superior in root yield and sugar yield, to the commercial variety Kaweterma and, thus, recommended for commercial cultivation.

Basha and gomaa (1994) stated that sugar beet cultivars differed in root weight/plant, and root yield/fed. Such variation was also reported by Hassanin (1999) as Kawemira cultivars outyielded Pleno in root and sugar yields.

Hassanin and Ramadan (1999) found that sugar beet varieties differed significantly in root length, diameter, and weight in both seasons. These findings are in harmony with the findings of Mokadem (1999) and Ramadan (1999).

Abou- salama and El-Syaid (2000) found significant differences among varieties as Gazelle produced maximum root yield (tons/fed.). However, maximum sugar yield (ton/fed.) was produced by Oscarpoly due to its high quality index values.

Saif (2000) stated four sugar beet varieties viz. Macropoly, M9680, M9681 and Mito. She found significant differences among varieties in root fresh weight, sucrose, purity and root yield.

Jarvis et al. (2001) tested that two sugar beet varieties (Erect and Prostrate) were used to determine potential differences in yield. Variation in growth habit was not significant and yield differences among varieties were merely attributed to their response to cultural conditions.

Ismail (2002) found that sugar beet varieties did not differ significantly in root length and diameter as well as sucrose and purity \% in both seasons , while they varied significantly in root fresh weight (g/plant), root and sugar yield(ton/fed) in the $1^{\text {st }}$ season only. 
Abd El-Wahab et al (2005) showed that Top and Kawemira cvs. Recorded the highest root and sugar yields/fed. While Farida cv. in the first season and Kawemira in the second one gave the highest top yield/fed.

Ibrahim et al. (2005) found that Kawemira and Farida varieties used in their study produced the highest sugar yield ton/feddan (3.458 tons) for Farida and (2.899 tons) for Kawemira variety.

Osman (2005) found that sugar beet variety Kawemira surpassed the variety Pleno in leaf/root weight ratio, root diameter, root fresh weight, total soluble solids, sucrose and purity in both season.

Gaber et al. (2006) tested three sugar beet varieties (Samba, Gazille and Helious). The obtained data revealed that Gazelle variety surpassed the other varieties in root yield (27.75 ton/fed.) and sugar yield (4.46 ton/fed.)

Geweifel et al. (2006a) their results showed that Samba cv. Recorded the highest top, root and gross sugar yields/ha, while Demapoly cv. produced the highest purity .

Geweifel et al. (2006b) found that Baraca cv. Showed better adaptation to the prevailing environmental conditions in Egypt and gave the highest sugar yield/ha. However, Demapoly cultivar surpassed the other two cultivars in root and top yields.

Ahmed (2008) evaluated 12 sugar beet varieties for yield and its components. He found that Helma and Del 938 cultivars had the highest value of sucrose $\%$ and purity\% and sugar yield (ton/fed.) without significant differences between them. However Univers, Kawemira, Monte Bianco and Del 937 varieties gave the highest values of root yield without significant differences between them.

This work was carried out to evaluate the performance of seven Monogerm and seven Multi-germ sugar beet cultivars for their yield and its attributes under north Delta conditions. The work is part of the research thesis of the first author for PhD degree.

\section{MATERIALS AND METHODS}

This work was carried out during 2008-2009 and 2009-2010 seasons to evaluate fourteen imported sugar beet cultivar under the farm conditions of Abo Taha village, Belkas district, Dakahlia Governorate (latitude $31^{\circ} 15^{\prime} \mathrm{N}$ ) to determine their merit as possible candidates to be distributed to farmers. The work is part of the research thesis of the first author for $\mathrm{PhD}$ degree. The tested multi-germ cultivars Monte Bianco, Monte Baldo, Monte Rosa, Swallow, and Top along with the mono-germ cultivars Henrike, BTS 899, and Beretta are imported from Germany. In addition, the multi-germ cultivars Capel, and Floima along with the mono-germ cultivars LP15, LP16, Avantage, and Lagon were imported from France. All cultivars were hand sown on October $20^{\text {th }}$ and $25^{\text {th }}$ in 2008 and 2009 seasons and maintained according to the recommendations of the Ministry of Agriculture. Harvest took place on May 22 $2^{\text {nd }}$ and 29 2009 and 2010 for the two seasons, respectively

The experimental design was a Randomized Completely block design with six replication in both seasons. The seed type comprising two 


\section{El-Kammash, T. N. et al.}

treatments that were then nested to contain seven cultivars within each type. Planting took place on ridges $50 \mathrm{~cm}$ wide and 3.5 meters long at a distance of $20 \mathrm{~cm}$ between hills. The cultivars were sown in six replicates experiment in plots $1 / 400$ of feddan $\left(10.5 \mathrm{~m}^{2}\right)$..Soil analysis of the experimental site is shown in Table 1.

Seedlings were thinned at the four leaf stage to one plant per hill.. Calcium super phosphate was added at the rate of $15 \mathrm{~kg} \mathrm{P}_{2} \mathrm{O}_{5} /$ feddan during soil preparation. Potassium fertilization was added in the form of potassium sulfate $48 \%$ at a rate of $24 \mathrm{~kg} \mathrm{~K} \mathrm{~K}_{2} \mathrm{O} /$ feddan after thinning. Nitrogen was applied in the form of urea at a rate of $80 \mathrm{~kg} /$ feddan added in two equal doses after thinning and one month later. At harvest four guarded ridges for every plot were taken to determine the yield and yield attributes and then random sample of ten plants was taken from each plot to determine the following measurements.:

1-Root fresh weight (kg/plant).

2-Top fresh weight ( $\mathrm{kg} / \mathrm{plant})$.

3-Root diameter $(\mathrm{cm})$.

4- Root yield (ton/fed.).

5-Top yield(ton/fed.).

A sample of $10 \mathrm{~kg}$ roots was collected from each plot and shipped to the quality laboratory of the Dakahlia Sugar Company to determine the quality parameters. Quality traits; i.e. Pol \% (sucrose \%), Potassium, Sodium and Alpha amino nitrogen (meq/100g) were measured according to Reinfield et al. (1974). These traits were used to calculate the following parameters that were used to estimate gross and recoverable sugar yield (ton/ feddan) as follows:

$$
\text { Quality index: }=100[100-(\mathrm{D} / \mathrm{Pol})]
$$

Where, $D=0.343(k+N a)+0.094(\alpha$-amino N $)+0.29$

Sugar loss $\%=0.343(\mathrm{~K}+\mathrm{Na})+0.094(\alpha$-amino $N)-0.31$

Theoretical sugar recovery $\%=\mathrm{Pol}-(0.029+0.343(\mathrm{~K}+\mathrm{Na})+0.094 \alpha$-amino $\mathrm{N})$. Where, pol, $\mathrm{K}$ and $\mathrm{Na}$ refer to sucrose $\%$, potassium and sodium in( $\mathrm{meq} / 100$ $\mathrm{g}$ beet), respectively.

Table 1: Mean values of some physical and chemical properties of the experimental site.

\begin{tabular}{|l|c|}
\hline \multicolumn{1}{|c|}{ Variable } & Value \\
\hline Physical analysis & 24.8 \\
\hline Sand \% & 32.8 \\
\hline Silt \% & 42.4 \\
\hline Clay \% & Clay \\
\hline Texture class & \\
\hline Chemical analysis & 7.8 \\
\hline Soil reaction pH & 4 \\
\hline EC (mmohs/cm) & 182.0 \\
\hline Available N ppm & 6.79 \\
\hline Available P ppm & 358.0 \\
\hline Available K ppm & 27.21 \\
\hline Na+ (meq/L) & 0.19 \\
\hline $\mathrm{K}+$ (meq/L) & \\
\hline
\end{tabular}




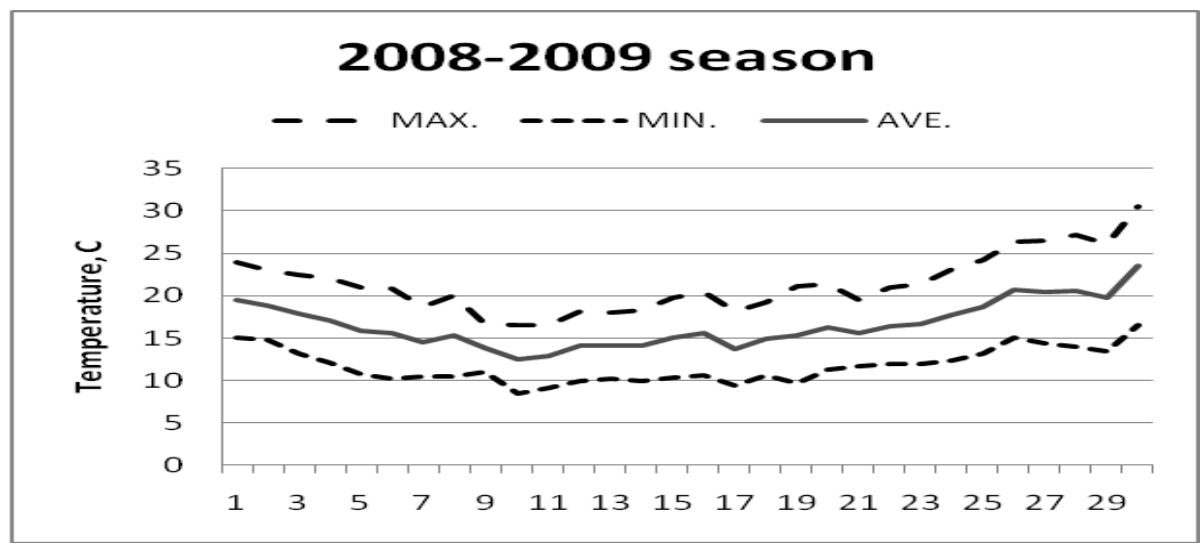

Age, weeks

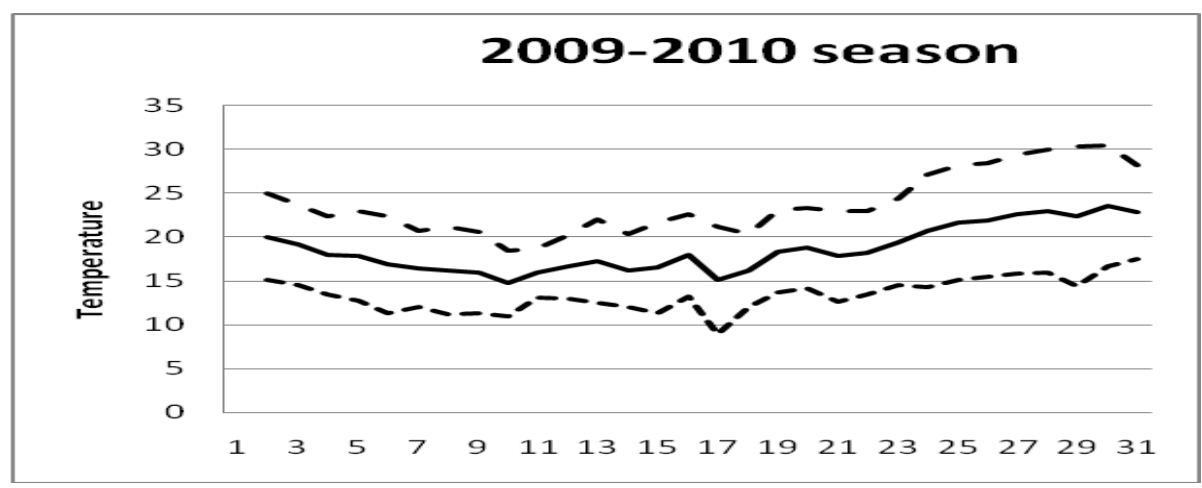

Age, weeks

Fig. 1: Minimum, maximum and average weekly temperature recorded during the two experimental seasons.

The collected data were subjected to statistical analysis. The model used separated the SS of the fourteen cultivars into contrasts of seed type, the tested each seed type to calculate the SS of mono- or multi- cultivars within its group. Significant means were compared using LSD at $5 \%$ probability level according to Gomez and Gomez (1984).

\section{RESULTS AND DISCUSSION}

Data in Table 2 represent the means of major plant characteristics for the two seasons. It indicates that cultivars' differences were highly significant in both seasons, for all traits except for top fresh weight in the first season. However, seed type showed insignificant response in terms of all traits in both seasons except for root fresh weight (first season) and root/top ratio in the second season. 
El-Kammash, T. N. et al.

2 
In addition, cultivars differences within multigerm type were significant except for top fresh weight in the first season. Similar trend was observed within the mono-germ group with the exception for top fresh weight of both seasons. Similar conclusions were reported by Mokadem (1999), Abou-Salama and ElSaid (2000), Saif (2000), Ismail (2002), Osman (2005), and Geweifel et la. (2006a)

Over the two experimental seasons, the first season recorded values were less than that of second season in terms of root and top weights. This could be attributed to the differences recorded in temperature of both season. The early growth stage in the first season temperature was relatively lower than that of the second season. Warm temperature is known to enhance root and top growth particularly in the early stage of seedling establishment. Means comparisons indicates that, over all cultivars, the cultivar Lp16 (monogerm) recorded the highest root fresh weight in both seasons. These findings are similar to those of Ramadan (1999), Abou-Salama and El-Said (2000), Saif (2000), Ismail (2002), Osman (2005), Abd El-wahab et al. (2005), Gaber et al. (2006) and Ahmed (2008). Several other cultivars showed statistically similar weights. However, the ones with high stability for both seasons from the mono-germ group were Lp15 and BTS 899. In addition, Monte Bianco and Capel showed stable response in the multi-germ group. When root diameter is taken into account, it is clear that the cultivars that recorded the highest root weight maintained their superiority by attaining maximum values of root diameter as found in table 2. As for top weight, it is evident that the cool first season had similar effect on all cultivar as the response was insignificant. However, the warm temperature of the second season induced top growth for several cultivars in the second season with Bretta (mono-germ) recording the highest top weight.

Table 3 represents the yield parameters of the two experimental seasons in addition to the quality index calculated from all quality traits. As root yield in mainly controlled by individual root weight, the data indicated that the maximum values recorded were obtained from Lp16 and BTS 899 (both Mono-germ) in addition to Monte Bianco and Capel cultivars (multigerm) in both season. These pre-mentioned cultivars also produced high values of top yield per feddan. However, several other cultivars also produced statistically similar values of top yield but failed to produce high root yield per feddan such as Lp15 cultivars (monogerm) and Top cultivar (multigerm). These differences in response could be attributed to the genetic makeup of the cultivars that controls assimilate distribution within the plants.

Results in Table 3 showed that Quality index data shown in table 3 reveal that the cool weather in first season could be accounted for high values of quality index for all cultivars.

As for the gross and recoverable sugar yields, it is clear that the cool weather in the first season affected the overall response of all cultivars. The values recorded in the first season for these traits were higher than the next one. This is logic since cool weather tends to reduce growth and enhance sugar accumulation at the end of the season. Most of the examined cultivars produced statistically similar high values for gross and recoverable sugar yield in the first season with only three cultivars falling behind. 
El-Kammash, T. N. et al.

3

542 
However, in the second season, only Lp16 and Monte Bianco maintained such superiority for gross sugar yield. Furthermore, the most stable cultivars in term of recoverable sugar yield that maintain its high values in the two seasons were the mono-germ cultivars namely; Lagon, Lp15 and Lp 16. The cultivar Lp16 in particular, maintained its high recoverable sugar yield as a result of its high root yield rather than quality index. On the other hand, the cultivar Monte Bianco lost its superiority in the second season mainly due to its low quality index value. Such findings were also found by Abou-Salama and El-Said (2000), Saif (2000), Osman (2005), Geweifel et al. (2006a), and Ahmed (2008).

This work suggests that the three cultivars Lagon, Lp15 and Lp 16(monogerm) and Monte bianco, Capel (multigerm) could be evaluated under different environments for stability before recommending them for cultivation.

\section{REFERENCES}

Abd El-Wahab, A.M.; H.M. Abd El-Mottaleb and M.S.H. Yussef (2005). Response of some sugar beet cultivars to two fertilization treatment under sprinkler and drip irrigation system in newly reclaimed lands, Sina. The 11th Conference of Agronomy, Agronomy. Dept., Faculty of Agric., Assiut Univ., Nov. 15-16, 613-624.

Abou-Salama, A.M. and S.I. El-Syiad (2000). Studies on some sugar beet cultivars under middle Egypt conditions. 1- Response to planting and harvesting dates. Assiut J. of Agric. Sci., 31 (1): 137-159.

Ahmed, A. (2008). Studies on the effect of genetic and environmental factors on yield and its components of some sugar beet varieties. Ph.D. Fac. Of Agric. Tanta, Univ.

Ahmed, G; S; Khan, Rahman, and M. Ali (1998). Evaluation of sugar beet varieties for root yield and quality parameter under Peshawar Valley conditions. Pakistan Sugar Journal. 13(2): 11-14.

Basha, H.A. and M.A. Gomaa (1994). Effect of harvesting date on yield and quality of two sugar beet cultivars. Egypt. J. Appl. Sci., 9 (5): 44-62.

Gaber, E.I.; M.A. Farag; Y. Samia Mahmoud and A. Nouran Basyoni (2006). Effect of seed size on germination yield and juice of some sugar beet varieties. Egypt. J. Agric. Res., 84 (6): 1843-1868.

Geweifle, H.G.M.; A.E.A. Omar and M.M. Ouda Sohier (2006a). Increasing sugar beet productivity in newly reclaimed sandy soil in Egypt. Proc. Inter. Symp. on Technologies to Improve Sugar Productivity in Developing Countries, Guilin, P.R. China, pp. 195-199

Geweifle, H.G.M.; A.A. Assey and Gehan A. Amin (2006b). Improving productivity and quality of some sugar beet cultivars through bio and mineral nitrogen fertilization in Egypt. Proc. Inter. Symp. on Technologies to Improve Sugar Productivity in Developing Countries, Guilin, P.R. China. Pp. 204-208. 
Gomez, K. and A.A. Gomez (1984). Statistical Procedures for Agriculture Research. A Wiley Interscience Publication, John Wiley and Sons. Inc. New York, USA.

Hassanin, M.A. (1991). Yield response of some sugar beet varieties to thinning and harvesting dates. Bull. Fac. of Agric., Univ., of Cairo, 42 (3): 673-686.

Hassanin, M.A. (1999). Effect of harvesting dates and nitrogen fertilization on yield and quality of some sugar beet varieties. Proceeding 1st Congress on Recent Technologies In Agric. Cario Univ. Faculty of Agric, Vol. II, 356-363.

Hassanin, M.A. and B.H. Ramadan (1999). Influence of plant densities and distribution on performance of some sugar beet varieties (Beta vulgaris L.). Proceeding 1st Congress on Recent Technologies In Agric. Cario Univ., Faculty of Agric (Vol. II): 315-321.

Ibrahim, M.M.; Kh.A.O. El-Aref and A.S. Abo El-Hamd (2005). Effect of nitrogen and phosphorus fertilization on yield and quality of two sugar beet varieties under Assiut Governorate condition. Zagazig J. Agric. Res., 32 (4): 1087-1103.

Ismail, A.M. (2002). Evaluation of some sugar beet varieties under different nitrogen levels at El-Fayoum. Egypt. J. Appl. Sci., 17 (2): 75-85.

Jarvis,-P; S Leeds and B.Cormack (2001).Organic sugar beet production in the UK. British Sugar Beet Review. 69(3): 10-11.

Jassem, M. (1982).Characters and value of sugar beet varieties cultivated in Poland. Zucherindustrie. 106(12):1044. [C. F. Plant Breeding Abst. 53(2): 1502].

Mokadem, Sh.A. (1999). Effect of varying sowing dates of some sugar beet cultivars under El-Minia condition. Zagazig J. Agric. Res., 26 (2): 253266.

Osman, A.M.H. (2005). Influence of nitrogen and potassium fertilization on yield and quality of two sugar beet varieties. Egypt. J. Agric. Res., 83 (3): 1237-1254.

Ramadan,B.S.H.(1999). Differential response of some sugar beet varieties to plant density and harvesting dates. J.Agric Sci.Mansoura univ., 24(2): 413-423.

Reinfeld, E.; A.E.M. Merich; G. Baumgarten; C. Winner and U. Besis (1974). Zur Voraussage des melassezyu cherus aus Ru beanalysen. Zucker (27): 2-15. The Sugar beet Crop, D.A. Cooke and R.K. Scott, (ed.). $1^{\text {st }}$ ed. Chapman and Hall (World Crop Series). London, U.K.

Said, E.M. (1993). Evaluation of some sugar beet cultivars under local environmental condition of Dakahlia province. J. Agric. Sci., Mansoura Univ., 18 (1): 11-16.

Saif, Laila, M.A. (2000). The relative importance of potassium fertilizer for sugar beet under Upper Egypt condition. Minufiya J. Agric. Res., 25 (5): 1215-1227.

Szklarz J. and S. Wojcik, (1983). Comparison of physical traits and yield of some sugar beet varieties grown on loess soil. Annales Universitatis Mariae Curie Sklodowska, E, Agricultura.38-39:p.135-143. 
Tripathi,B.K.,; Singh,D. and G.P. Misra (1986). Breeding sugar beet for short duration cropping on subtropical regions of India. India. J. Sugar beet Tech. (3):84-87.

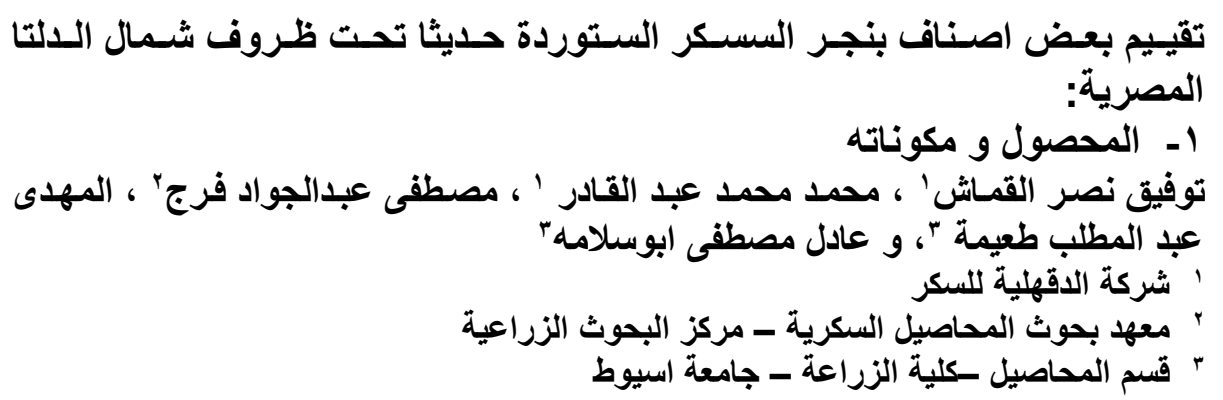

نفذ هذا البحث لتقييم اربعة عشر صنف بنجر سكر مستورد تحت الظروف الحقلية لهنطقة

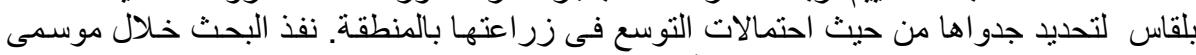

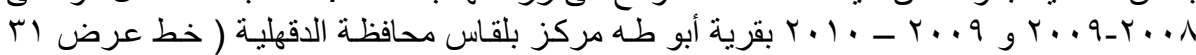

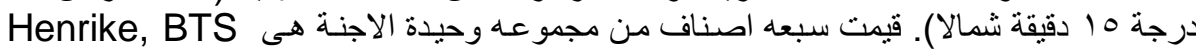
899, Beretta, Lagon, LP15, LP16, and Avantage Monte Bianco, Monte Baldo, Monte Rosa , زتنمى للمجمو عة متعددة الاجنة و هى ro , r. زرعت جميع الاصناف يدويافى . Swallow, Top, Capel, and Floima

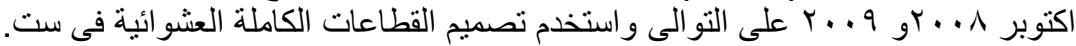

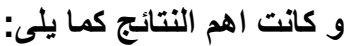

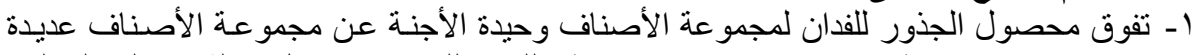

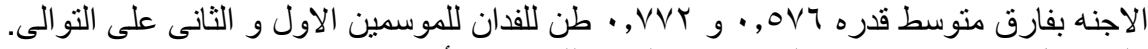

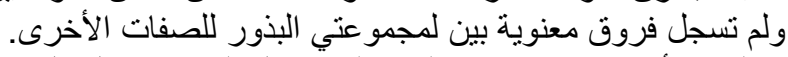

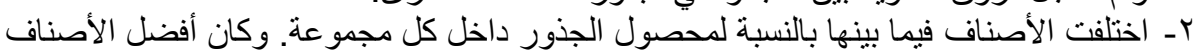

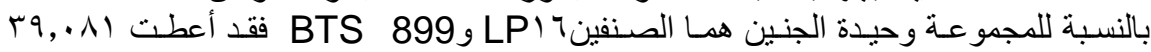

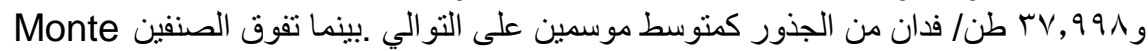

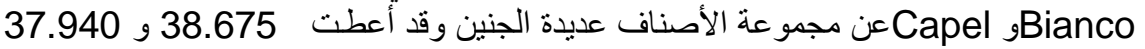

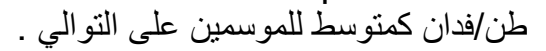

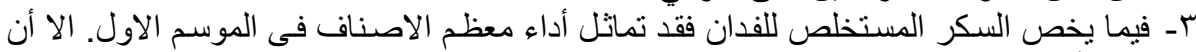

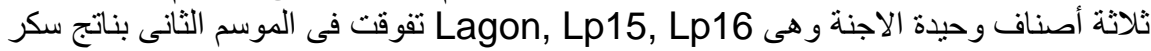

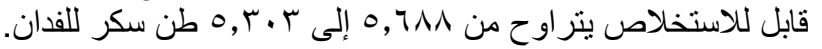

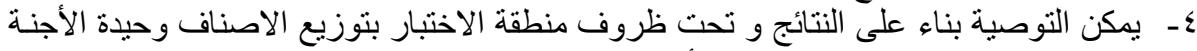

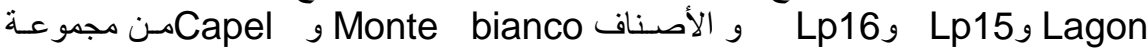

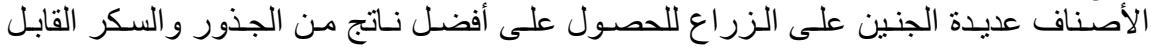
ليتخلاص من الفدان.

كلية الزراعة - جامعة المنصورة كلية الزراعة ـ جامعة القاهرة
قام بتحكيم البحث

أ.د / محسن عبد العزيز بدوى البد العيد

أ.د / ألسيد عبد العزيز محمود العزيز بدوى 
El-Kammash, T. N. et al. 
Table 2:Means of plant characteristics at harvest ( $\mathrm{gm} / \mathrm{plant}$ ) of fourteen sugar beet cultivars during both 20082009 and $2009-2010$ seasons.

\begin{tabular}{|c|c|c|c|c|c|c|c|c|c|c|c|c|c|}
\hline \multirow{2}{*}{$\begin{array}{l}\text { Seed } \\
\text { type }\end{array}$} & \multirow[b]{2}{*}{ Cultivars } & \multicolumn{2}{|c|}{ Root fresh wt., kg } & \multirow[b]{2}{*}{ Mean, } & \multicolumn{2}{|c|}{ Top fresh wt, kg } & \multirow[b]{2}{*}{ Mean } & \multicolumn{2}{|c|}{ Root/ top ratio } & \multirow[b]{2}{*}{ Mean } & \multicolumn{2}{|c|}{ Root diameter, cm } & \multirow[b]{2}{*}{ Mean } \\
\hline & & $2008-2009$ & $\begin{array}{l}2009- \\
2010\end{array}$ & & 200 & $\begin{array}{l}2009- \\
2010 \\
\end{array}$ & & $2008-2009$ & $9 \begin{array}{c}2009- \\
2010\end{array}$ & & 2 & 0 & \\
\hline \multirow{8}{*}{ 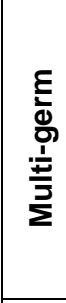 } & M.bianco & 1.192 & 1.220 & 1.206 & 0.400 & 0.421 & 0.411 & 3.00 & 2.91 & 2.96 & 11.95 & 12.15 & 12.05 \\
\hline & M.baldo & 1.151 & 1.186 & 1.169 & 0.387 & 0.408 & 0.398 & 2.98 & 2.75 & 2.87 & 11.52 & 11.78 & 11.65 \\
\hline & M.rosa & 0.998 & 1.110 & 1.054 & 0.384 & 0.395 & 0.390 & 2.62 & 3.03 & 2.83 & 10.72 & 11.09 & 10.91 \\
\hline & Swallow & 1.112 & 1.156 & 1.134 & 0.366 & 0.422 & 0.394 & 3.05 & 2.67 & 2.86 & 11.46 & 11.64 & 11.55 \\
\hline & Top & 1.143 & 1.171 & 1.157 & 0.410 & 0.440 & 0.425 & 2.81 & 2.67 & 2.74 & 11.76 & 11.83 & 11.80 \\
\hline & Capel & 1.188 & 1.213 & 1.201 & 0.393 & 0.426 & 0.410 & 3.03 & 2.85 & 2.94 & 11.82 & 12.02 & 11.92 \\
\hline & Floima & 1.160 & 1.189 & 1.175 & 0.371 & 0.394 & 0.383 & 3.16 & 3.02 & 3.09 & 11.60 & 11.75 & 11.68 \\
\hline & Mean & 1.135 & 1.178 & 1.156 & 0.387 & 0.415 & 0.401 & 2.950 & 2.843 & 2.896 & 11.547 & 11.751 & 11.65 \\
\hline \multirow{8}{*}{ 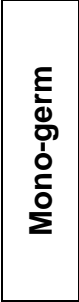 } & Henrike & 1.103 & 1.121 & 1.112 & 0.415 & 0.354 & 0.385 & 2.67 & 3.28 & 2.98 & 11.12 & 11.26 & 11.19 \\
\hline & BTS 899 & 1.190 & 1.201 & 1.196 & 0.403 & 0.423 & 0.413 & 2.96 & 2.96 & 2.96 & 11.72 & 11.82 & 11.77 \\
\hline & Beretta & 1.162 & 1.174 & 1.168 & 0.380 & 0.451 & 0.416 & 3.08 & 2.62 & 2.85 & 11.57 & 11.67 & 11.62 \\
\hline & Lagon & 1.156 & 1.172 & 1.164 & 0.375 & 0.375 & 0.375 & 3.09 & 3.13 & 3.11 & 11.50 & 11.68 & 11.59 \\
\hline & Lp15 & 1.181 & 1.198 & 1.190 & 0.392 & 0.410 & 0.401 & 3.02 & 2.95 & 2.99 & 11.62 & 11.95 & 11.79 \\
\hline & Lp16 & 1.204 & 1.237 & 1.221 & 0.402 & 0.435 & 0.419 & 3.00 & 2.76 & 2.88 & 12.11 & 12.34 & 12.23 \\
\hline & Avantage & 1.170 & 1.189 & 1.180 & 0.392 & 0.376 & 0.384 & 2.98 & 3.20 & 3.09 & 11.66 & 11.93 & 11.80 \\
\hline & Mean & 1.167 & 1.185 & 1.176 & 0.394 & 0.403 & 0.399 & 2.971 & 2.986 & 2.979 & 11.614 & 11.807 & 11.71 \\
\hline Gran & d mean & 1.151 & 1.181 & 1.166 & 0.391 & 0.409 & 0.400 & 2.961 & 2.914 & 2.938 & 11.581 & 11.779 & 11.68 \\
\hline \multicolumn{5}{|c|}{$\begin{array}{l}\text { LSD. } 0.05 \\
\text { Seed type } \\
\text { Cultivars within multi } \\
\text { Cultivars within mono } \\
\text { Among cultivars }\end{array}$} & ${ }^{\star \star} 0$. & $\begin{array}{l}049 \\
049 \\
049\end{array}$ & $\begin{array}{c}\text { Ns } \\
{ }^{\star *} 0.374 \\
{ }^{*} 0.374 \\
{ }^{\star *} 0.374\end{array}$ & $\begin{array}{l}\text { Ns } \\
\text { Ns } \\
\text { Ns } \\
\text { Ns }\end{array}$ & $\begin{array}{l}\text { Ns } \\
0.038 \\
\text { Ns } \\
* 0.038\end{array}$ & $\begin{array}{c}\text { Ns } \\
{ }^{*} 0.247 \\
{ }^{\star \star} 0.247 \\
{ }^{\star \star} 0.247\end{array}$ & $\begin{array}{c}{ }^{\star *} \\
{ }^{\star *} 0.271 \\
{ }^{*} 0.271 \\
{ }^{*} 0.271\end{array}$ & $\begin{array}{c}\mathrm{Ns} \\
{ }^{*} 0.550 \\
{ }^{* \star} 0.550 \\
{ }^{\star} 0.550\end{array}$ & $\begin{array}{c}\mathrm{Ns} \\
{ }^{\star *} 0.483 \\
{ }^{*} 0.483 \\
{ }^{* *} 0.483\end{array}$ \\
\hline
\end{tabular}


Table 3: Yield parameters of fourteen sugar beet cultivars (ton/fed.) in 2008-2009 and 2009-2010 seasons.

\begin{tabular}{|c|c|c|c|c|c|c|c|c|c|c|c|c|c|c|c|c|}
\hline \multirow[b]{2}{*}{$\begin{array}{l}\text { Seed } \\
\text { type }\end{array}$} & \multirow[b]{2}{*}{ ultivars } & \multicolumn{2}{|c|}{ Root yield } & \multirow[b]{2}{*}{ Mean } & \multicolumn{2}{|c|}{ Top yield } & \multirow[b]{2}{*}{ Mean } & \multicolumn{2}{|c|}{ Gross sugar yield } & \multicolumn{3}{|c|}{ Quality index } & \multirow[b]{2}{*}{ Mean } & \multicolumn{3}{|c|}{ Recoverable sugar yield } \\
\hline & & ד & \begin{tabular}{|l}
$2009-$ \\
2010
\end{tabular} & & & $\begin{array}{l}2009- \\
2010\end{array}$ & & $2008-2009$ & $\begin{array}{l}2009- \\
2010\end{array}$ & Mean & $\begin{array}{c}2008- \\
2009\end{array}$ & \begin{tabular}{|c|}
$2009-$ \\
2010
\end{tabular} & & 2009 & 10 & \\
\hline \multirow{8}{*}{ 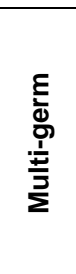 } & inco & 37.936 & 39.414 & 675 & 2.696 & 12.984 & 840 & 6.247 & 6.080 & 6.164 & 80.522 & 78.569 & 79.546 & 442 & 219 & \\
\hline & & & 36.686 & 36.148 & & 12.212 & 12.092 & & & & & 34 & 2.360 & & & \\
\hline & $M r$ & & & & & & & & & & & & & & & \\
\hline & Swallow & 4 & \begin{tabular}{|l|}
34.786 \\
\end{tabular} & 34.275 & & 11.500 & & & 5.632 & 5.939 & & \begin{tabular}{|c|}
81.758 \\
\end{tabular} & 83.227 & & & \\
\hline & Top & & 35.663 & 35.279 & & 12.449 & & & & 6.060 & & & 82.635 & & & \\
\hline & & & 38.262 & 37.940 & & 12. & & & & & & & 80 & & & \\
\hline & & & 37.001 & 36.513 & & 12.128 & & & 5.840 & 5.910 & 82.124 & 30.842 & 81.483 & & & \\
\hline & Mean & & \begin{tabular}{|l|}
36.057 \\
\end{tabular} & & & 12.148 & & & 5.774 & 5.920 & 82.976 & 80.996 & 81.986 & & & \\
\hline \multirow{8}{*}{ 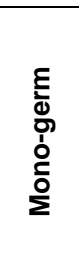 } & & & & & & & & & & & & & & & & \\
\hline & & & \begin{tabular}{|l|}
38.644 \\
\end{tabular} & 38 & & 12.848 & & & 6.049 & & 80. & & 79.989 & & & \\
\hline & Beret & 35.716 & 37.415 & 36.566 & 1.662 & 11.921 & 11.792 & 6.177 & 5.886 & \begin{tabular}{|l|}
6.032 \\
\end{tabular} & 82.924 & 80.909 & 81.917 & & 67 & \\
\hline & Lagc & & 37.184 & 36.492 & & 11.903 & & & 6.005 & & 83. & & 82.601 & & & \\
\hline & Lp15 & & 37.439 & & & 12.5 & & & 6.051 & & & & & & & \\
\hline & Lp16 & .443 & \begin{tabular}{|l|}
39.719 \\
\end{tabular} & 39.081 & & 13.128 & & 461 & 6.448 & 6.455 & 81.732 & 80.812 & 81.272 & & & \\
\hline & Avar & 35.326 & 36.988 & 36.157 & 54 & 12.104 & & & 5.897 & 6.028 & 84.346 & 62 & 83.154 & & & \\
\hline & $\overline{\mathrm{Me}}$ & & 36.8 & & & 12.250 & & & 5.905 & & & & 32.170 & & & \\
\hline \multicolumn{2}{|c|}{ rand mean } & 35.189 & 36.443 & 35.816 & 1923 & 12.199 & 12.061 & 6.072 & 5.839 & & 83.021 & & .078 & 82.078 & 129 & \\
\hline
\end{tabular}

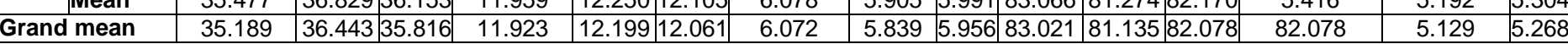
LSD. 0.05

Seed type

Cultivars within multi

Cultivars within mono$$
\text { * }
$$

* Ns

Ns Ns Ns Ns

Ns Ns Ns

${ }^{\star *} 1.258 \quad * * 1.1764 \quad * 0.994$

${ }^{* *} 0.814 \quad * * 0.425 \quad * * 0.357{ }^{* *} 1.1688{ }^{* *} 1.658 \quad * * 0.427 \quad * * 0.346$

Among cultivars

${ }^{* *} 1.2588^{* *} 1.1764 \quad * * 0.994$ 
J. Plant Production, Mansoura Univ., Vol. 2 (4), April, 2011 